\title{
KUMUR-KUMUR EKSTRAK MENGKUDU DAPAT MENGHAMBAT PERTUMBUHAN STREPTOKOKUS $S p$ SEBAGAI PENYEBAB TERJADINYA PLAK GIGI
}

\author{
(NONI EXTRACT MOUTHWASH CAN INHIBIT THE GROWTH OF \\ (STREPTOCOCUS Sp) THE CAUSE OF DENTAL PLAQUE)
}

\author{
I Gusti Agung Ayu Dharmawati, I Gusti Agung Ayu Putu Swastini, Ni Made Widhiasti \\ Jurusan Keperawatan Gigi Poltekkes Denpasar \\ Jl. P Moyo no 33 Denpasar \\ E-mail: ayu_dharmawati@yahoo.com
}

\begin{abstract}
Noni is a traditional crop that can be used to rinse-and contains of antibacterial mouthwash. This study aimed to determine the effects of mouthwash-gargle noni extract in inhibiting the growth of (Streptococus sp). This study used randomized pre and posttest control group design. The subjects were 21 persons taken by simple random sampling. The experimental materials were noni extract concentration of 50\% and 75\%. Data was tested using Kruskal-Wallis test followed by Mann-Whitney test and Wilcoxon.The results showed a significant different result on the amount growth of Streptococus sp after treatment $(\mathrm{p}<0.02)$. A significant different result showed between control group $(0.2 \%$ khlorhexidin) and noni extract $50 \%$ and $75 \%(p<0.05)$. There was no significant difference between noni extract $50 \%$ and $75 \%(p>0.05)$. Test analysis of each group before and after treatment showed that there was a very significant decline in the number of Streptococus sp growth using chlorhexidin $0.2 \%$ and noni extract $50 \%$ ( $\mathrm{p}<0.05)$, and insignificantly different result when using noni extract $50 \%(\mathrm{P}<0.05)$ and noni extract $75 \%(\mathrm{p}>0.05)$. Noni extract $50 \%$ and $75 \%$ have the effects of inhibiting the growth of Streptococus $\mathrm{sp}$ as the cause of the formation of dental plaque. However the increasing concentration of $50 \%$ to $75 \%$ did not significantly affect the increased inhibition of noni extract. In conclusion, noni extract mouthwash $50 \%$ and $75 \%$ can inhibit the growth of Streptococus mutans.
\end{abstract}

Key words: noni extract, Streptococus sp, dental plaque growth

\begin{abstract}
Abstrak
Mengkudu merupakan tanaman tradisional yang dapat digunakan untuk berkumur dan mengandung antibakteri. Penelitian bertujuan untuk mengetahui efek berkumur ekstrak mengkudu dalam menghambat pertumbuhan Streptokokus sp. dilaksanakan dengan metode completely randomized pre dan post test control group design. Pengambilan sampel 21 orang secara simple random sampling. Bahan eksperimen menggunakan ekstrak mengkudu konsentrasi $50 \%$ dan $75 \%$. Data hasil penelitian diuji dengan Kruskal-Wallis, Mann-Whitney dan Wilcoxon. Hasil analisis menunjukkan ada perbedaan bermakna pada pertumbuhan Streptokokus $s p$ setelah perlakuan $(\mathrm{p}<0,02)$. Berbeda bermakna pada kelompok kontrol (khlorhexidin 0,2\%) dengan ekstrak mengkudu 50\% dan 75\% ( $\mathrm{p}<0,05$ ), tidak berbeda bermakna antara ekstrak mengkudu 50\% dengan $75 \%$ ( $>$ > 0,05). Uji analisis masing- masing kelompok sebelum dan setelah perlakuan menunjukkan berbeda bermakna pada khlorhexidin 0,2\% dengan ekstrak mengkudu $50 \%(\mathrm{p}<0,05)$ dan tidak berbeda bermakna dengan ekstrak mengkudu 75\% (p>0,05). Kumur-kumur ekstrak mengkudu 50\% dan 75\% dapat menghambat pertumbuhan Streptokokus sp. penyebab dental plak, tetapi peningkatan konsentrasi dari 50\% menjadi $75 \%$ tidak berpengaruh terhadap peningkatan daya hambat dari ekstrak mengkudu. Disimpulkan, kumur-kumur ekstrak mengkudu $50 \%$ dan $75 \%$ dapat menghambat pertumbuhan Streptokokus $s p$.
\end{abstract}

Kata kunci: ekstrak mengkudu, Streptokokus $s p$, plak gigi

\section{PENDAHULUAN}

Kesehatan gigi dan mulut mempunyai peranan penting bagi kesehatan dan kesejahteraan tubuh secara umum. Gangguan yang terjadi baik pada jaringan keras maupun jaringan pendukung gigi akan berdampak pada produktivitas seseorang. Prevalens masalah gigi dan mulut di Indonesia sebesar 
25,9\% dengan 14 provinsi memiliki prevalens di atas angka nasional. Prevalens indeks DMFT secara nasional 4,6 tetapi terdapat 15 provinsi yang memiliki prevalens di atas angka nasional. ${ }^{1}$ Hasil studi morbiditas SKRT (Survei Kesehatan Rumah Tangga) dan survei yang dilakukan Departemen Kesehatan RI tahun 2007, menunjukkan bahwa secara umum prevalens penyakit gigi dan mulut tertinggi meliputi $72,1 \%$ penduduk dan $46,6 \%$ merupakan karies aktif. ${ }^{2}$

Plak gigi merupakan suatu deposit lunak yang melekat erat pada permukaan gigi, terdiri atas mikroorganisme yang berkembang biak dalam suatu matriks intraseluler apabila seseorang mengabaikan kebersihan gigi dan mulut. ${ }^{3}$ Plak yang melekat erat pada permukaan gigi dan gingiva mempunyai potensi yang cukup besar terhadap terjadinya penyakit jaringan keras gigi (karies gigi) maupun jaringan pendukungnya (periodontitis). ${ }^{4}$

Jenis bakteri utama yang terdapat dalam plak gigi adalah beberapa strain Streptokokus yang mempunyai kemampuan untuk membentuk polisakarida ekstraseluler. Streptokokus adalah bakteri sferis Gram positif yang khasnya berpasangan atau membentuk rantai selama pertumbuhannya. Organisme ini banyak terdapat di alam dan merupakan flora normal di rongga mulut. ${ }^{5,6}$

Sebagian besar masalah kesehatan gigi dan mulut sebenarnya dapat dicegah. Miller menyatakan bahwa berdasarkan teori chemico parasitic, karies dapat dicegah dengan antibakteri berupa obat kumur untuk mengurangi dan mencegah terbentuknya plak.,4 Obat kumur dapat mengontrol terbentuknya dan memperlambat proses maturasi (pematangan) plak gigi yang merupakan proses awal penyakit gigi dan mulut. $^{7}$

Selama 25 tahun khlorhexidin (CHX) digunakan sebagai obat kumur untuk mencegah terbentuknya plak gigi, sehingga CHX sering digunakan sebagai kontrol positif untuk penilaian potensi antikariogenik lainnya. ${ }^{8}$ Tidak semua masyarakat dapat dengan mudah memperoleh khlorhexidin. Mengkudu merupakan tanaman daerah tropis yang dapat dimanfaatkan untuk mengobati berbagai penyakit.

Penelitian perasan buah mengkudu yang dilakukan oleh Salomon melaporkan bahwa lebih dari $78 \%$ pasien yang mempunyai gangguan tenggorokan dan mulut dapat disembuhkan. ${ }^{9}$ Penelitian Raiyanti mengenai berkumur-kumur sari buah mengkudu menunjukkan adanya penurunan plak skor dari 0,47 menjadi $0,32 .{ }^{10}$ Pada penelitian aktivitas anti-bakteri ekstrak mengkudu menunjukkan bahwa ekstrak mengkudu memiliki daya hambat kuat terhadap bakteri Gram positif. ${ }^{11}$ Sebelumnya peneliti sudah pernah melakukan penelitian daya hambat ekstrak mengkudu terhadap bakteri Streptokokus mutans secara in vitro, menunjukkan ekstrak mengkudu memiliki daya hambat yang kuat terhadap bakteri Streptokokus mutans. ${ }^{12}$ Tujuan penelitian ini untuk mengetahui lebih lanjut efektivitas ekstrak mengkudu dalam menghambat pertumbuhan Streptokokus $s p$. apabila digunakan sebagai bahan kumur-kumur. Hasil penelitian ini diharapkan dapat dipergunakan bagi masyarakat umum yang berada jauh dari jangkauan dengan menyediakan obat kumur untuk menjaga kesehatan gigi dan mulutnya.

\section{BAHAN DAN METODE}

Jenis penelitian ini adalah eksperimen dengan metode completely randomized pre test-post test control group design. Sampel terdiri atas 21 orang dengan kriteria: memiliki susunan gigi lengkap, teratur sampai berjejal ringan. Secara simple random sampling sampel dikelompokkan menjadi 3 kelompok, masing-masing kelompok terdiri atas 7 orang. Bahan ekstrak mengkudu dipilih dari buah mengkudu yang matang, putih, transparan dan ukuran buahnya relatif besar. ${ }^{13}$

Sampel diberi penjelasan cara menyikat gigi dengan teknik kombinasi (Scrub \& Stillmann), dan dilakukan skeling sehingga tidak lagi ditemukan kalkulus dan sisa-sisa makanan yang menempel pada permukaan gigi. Sehari kemudian diambil sampel plak dengan swab pada masing-masing sampel untuk menghitung jumlah koloni Streptokokus $s p$ yang tumbuh sebelum perlakuan. Selanjutnya diberikan perlakuan pada kelompok kontrol (+) P0 berkumur dengan chlorhexidin $0,2 \%$, kelompok P1 berkumur dengan larutan ekstrak mengkudu 50\%, dan kelompok P2 berkumur dengan larutan ekstrak mengkudu $75 \%$. Berkumur-kumur dilakukan selama 2 menit, kemudian dibuang. Kemudian sampel penelitian selama 30 menit mengonsumsi biskuit dan roti yang telah disediakan peneliti dan selama 5 jam melakukan aktivitas seperti biasa. Setelah 5 jam, subyek penelitian pada masing-masing kelompok diswab dental plaknya untuk mengetahui pertumbuhan bakteri Streptokokus $s p$, dengan cara swab dental plak dimasukan ke dalam tabung yang berisi media TSB, kemudian diencerkan dengan 0,5 Mac Farland, kemudian spesimen ditanam dalam Mueller Hinton dan diinkubasi selama 24 jam pada suhu $37^{\circ} \mathrm{C}$. Selanjutnya jumlah bakteri dihitung dengan colony counter.

\section{HASIL}

Tabel 1 secara garis besar menunjukkan adanya 
penurunan jumlah Streptokokus $s p$ pada ketiga kelompok sampel setelah memperoleh perlakuan kumur-kumur baik dengan khlorhexidin 0,2\% dan ekstrak mengkudu 50\% dan $75 \%$.

Tabel 1. Hasil Uji Analisis Kruskal-Wallis pada kelompok sebelum dan sesudah perlakuan

\begin{tabular}{lcccc}
\hline \multicolumn{1}{c}{ Kelompok } & $\mathrm{n}$ & $\begin{array}{c}\text { Rerata rank } \\
\text { Streptokokus } s p \\
\left(10^{4}\right)\end{array}$ & df & $\mathrm{p}$ \\
\hline Sebelum perlakuan : & 7 & 09,93 & 2 & 0,248 \\
Khlorhexidin 0,2 \% & 7 & 14,14 & & \\
Ekstrak mengkudu 50\% & 7 & 08,93 & & \\
Ekstrak mengkudu 75\% & 7 & & & \\
Setelah perlakuan : & & & & \\
Khlorhexidin 0,2\% & 7 & 04,50 & 2 & 0,002 \\
Ekstrak mengkudu 50\% & 7 & 15,57 & & \\
Ekstrak mengkudu 75\% & 7 & 12,93 & &
\end{tabular}

Hasil uji Kruskal Wallis menunjukkan pada ketiga kelompok setelah perlakuan kumur-kumur khlorhexidin 0,2\%, ekstrak mengkudu 50\% dan $75 \%$ menunjukkan adanya penurunan pertumbuhan Streptokokus $s p$ yang bermakna pada $(\mathrm{p}<0,05)$. Untuk mengetahui pada kelompok mana saja yang berpengaruh terhadap penurunan jumlah Streptokokus $s p$, maka dilanjutkan dengan analisis antar kelompok menggunakan uji Mean Whitney.

Tabel 2. Hasil uji analisis Mann-Whitney antar kelompok perlakuan

\begin{tabular}{|c|c|c|c|}
\hline $\begin{array}{l}\text { Kelompok } \\
\text { Perlakuan }\end{array}$ & $\mathrm{n}$ & $\begin{array}{c}\text { Rerata Rank } \\
\text { Streptokokus } s p \\
\left(10^{4}\right)\end{array}$ & $\mathrm{p}$ \\
\hline $\begin{array}{l}\text { Khlorhexidin } 0,2 \% \text { dengan } \\
\text { ekstrak mengkudu } 50 \%\end{array}$ & 7 & $\begin{array}{l}04,00 \\
11,00\end{array}$ & 0,001 \\
\hline $\begin{array}{l}\text { Khlorhexidin } 0,2 \% \text { dengan } \\
\text { ekstrak mengkudu } 75 \%\end{array}$ & 7 & $\begin{array}{l}04,50 \\
10,50\end{array}$ & 0,003 \\
\hline $\begin{array}{l}\text { Ekstrak mengkudu } 50 \% \text { dengan } \\
\text { ekstrak mengkudu } 75 \%\end{array}$ & 7 & $\begin{array}{l}08,57 \\
06,43\end{array}$ & 0,336 \\
\hline
\end{tabular}

Uji Mean Whitney menunjukkan adanya perbedaan bermakna kumur-kumur menggunakan khlorhexidin 0,2\% dengan ekstrak mengkudu 50\% dan 75\% ( $\mathrm{p}<0,05$ ), dan tidak berbeda bermakna pada kumur-kumur antara ekstrak mengkudu 50\% dengan $75 \%$ ( $\mathrm{p}>0,05)$.

Untuk mengetahui adanya perbedaan penurunan yang bermakna pada masing-masing kelompok sebelum dan setelah diberikan perlakuan dilanjutkan dengan melakukan uji analisis Wilcoxon.

Tabel 3 menunjukkan adanya pertumbuhan Streptokokus $s p$ yang berbeda bermakna sebelum dan setelah diberikan perlakuan kumur-kumur khlorhexidin $0,2 \%(\mathrm{P}<0,05)$ dan kumur-kumur ekstrak mengkudu 50\% ( $\mathrm{p}<0,05)$. Sedangkan pada kumurkumur ekstrak mengkudu $75 \%$ tidak menunjukkan adanya penurunan jumlah pertumbuhan Streptokokus $s p$ yang berbeda bermakna $(\mathrm{p}>0,05)$.

Tabel 3. Hasil Uji Analisis Wilcoxon sebelum dan sesudah perlakuan pada masing-masing kelompok

\begin{tabular}{|c|c|c|c|}
\hline Kelompok perlakuan & $\mathrm{n}$ & $\begin{array}{c}\text { Rerata Rank } \\
\text { Streptokokus } s p \\
\left(10^{4}\right)\end{array}$ & $\mathrm{p}$ \\
\hline \multicolumn{4}{|l|}{ Khlorhexidin : } \\
\hline Sebelum perlakuan & 7 & 0,400 & 0,018 \\
\hline Sesudah perlakuan & 7 & 0,000 & \\
\hline \multicolumn{4}{|l|}{ Extrak Mengkudu $50 \%$ : } \\
\hline Sebelum perlakuan & 7 & 0,400 & 0,018 \\
\hline Setelah perlakuan & 7 & 0,000 & \\
\hline \multicolumn{4}{|l|}{ Extrak Mengkudu $75 \%$ : } \\
\hline Sebelum perlakuan & 7 & 4,200 & 0,237 \\
\hline Sesudah perlakuan & 7 & 3,500 & \\
\hline
\end{tabular}

\section{PEMBAHASAN}

Hasil penelitian menunjukkan tidak ada perbedaan yang bermakna jumlah Streptokokus $s p$ hasil swab plak subyek penelitian sebelum diberikan perlakuan pada kontrol dan ekstrak mengkudu 50 dan $70 \%$. Walaupun demikian setelah diberikan perlakuan kumur-kumur khlorhexidin dan extrak mengkudu terlihat ada perbedaan yang bermakna penurunan jumlah Streptokokus $s p$. dengan $p<00,5$ (Tabel 1). Hal ini menunjukkan bahwa ekstrak mengkudu dan khlorhexidin 0,2\% memiliki kemampuan yang hampir setara dalam menghambat pertumbuhan Streptokokus $s p$. Hasil analisis berbeda bermakna jumlah penurunan bakteri Streptokokus $s p$ pada pemakaian khlorhexidin dengan ekstrak mengkudu disebabkan khlorhexidin $0,2 \%$ merupakan zat kimia derivate bisbiqunite sebagai bahan kumur yang efektif dapat mengurangi plak pada gigi dan mempunyai spekturm luas, bekerja cepat dan toksisitasnya rendah, sedangkan terjadinya penurunan jumlah pertumbuhan Streptokokus $s p$ pada pemakaian ekstrak mengkudu karena mengkudu mengandung zat anti bakteri yaitu senyawa antraquinon, flavonoid, alkaloid, acubin dan alizarin yang dapat melawan bakteri Stahpylococus aureus, Bacillus subtilis, Protens morganii, Pseudomonas dan Escherichia coli. Zat anti bakteri ini juga dapat mengontrol bakteri patogen seperti Salmonella typhi, Shigella disentriae. ${ }^{14}$ Penelitian yang dilakukan Salomon melaporkan bahwa lebih dari $78 \%$ pasien yang mempunyai gangguan tenggorokan dan mulut dapat disembuhkan. ${ }^{9}$

Tabel 3 menunjukkan hasil berbeda bermakna pada penurunan jumlah pertumbuhan Streptokokus $s p$ antara kelompok kontrol (khlorhexidin 0,2\%) dengan ekstrak mengkudu $50 \%$, begitu juga antara 
kelompok kontrol (khlorhexidin 0,2\%) dengan ekstrak mengkudu $75 \%$ terdapat perbedaan yang bermakna. Diameter zona hambat umumnya cendrung meningkat sebanding dengan meningkatnya konsentrasi ekstrak, hal ini juga terjadi pada penelitian Jayaraman dkk. ${ }^{15}$ Perbandingan jumlah pertumbuhan Streptokokus $s p$ antara ekstrak mengkudu 50\% dengan $75 \%$ terdapat penurunan rerata jumlah pertumbuhan, tetapi tidak menunjukkan perbedaan yang bermakna (Tabel 3), hal ini menunjukkan bahwa konsentrasi ekstrak mengkudu 50\% saja sudah memberikan daya hambat kuat, sehingga dengan peningkatan konsentrasi tidak terjadi penurunan jumlah Streptokokus $s p$ yang lebih efektif. Hasil ini sesuai dengan penelitian Dewi terhadap bakteri Gram positif, yang mana diameter zona hambat tidak selalu sebanding dengan naiknya konsentrasi ekstrak mengkudu. ${ }^{11}$ Begitu pula pada penelitian Dharmawati yang mana dengan kenaikan konsentrasi ekstrak mengkudu tidak disertai dengan kenaikan daya hambat terhadap Streptokokus mutans. ${ }^{12}$ Terjadinya penurunan jumlah yang tidak sebanding dengan kenaikan konsentrasi disebabkan karena ekstrak etanol buah mengkudu bekerja tidak stabil pada penghambatan, terlihat bahwa konsentrasi yang semakin besar tidak memberikan efek penghambatan yang lebih besar. Hal ini mungkin disebabkan karena ekstrak yang digunakan merupakan ekstrak kasar yang kelarutan senyawa antibakterinya belum maksimal, sehingga aktivitasnya tidak maksimal pula. ${ }^{11}$ Pada penelitian ini pelarut yang digunakan pada pembuatan ekstrak adalah etanol yang merupakan pelarut universal, sehingga senyawa-senyawa lainnya yang bersifat polar banyak yang ikut tertarik ke dalam ekstrak. Hal ini menyebabkan aktivitas senyawa antibakteri yang diharapkan tidak optimal, karena bekerja secara sinergis dengan aktivitas senyawa-senyawa polar lain yang terkandung dalam ekstrak buah mengkudu. ${ }^{16}$ Untuk memperoleh daya hambat antibakteri yang optimal perlu dilakukan identifikasi senyawa flavornoid yang merupakan zat antibakteri utama pada buah mengkudu. ${ }^{17}$ Pada perbandingan jumlah penurunan Streptokokus $s p$ pada masing-masing kelompok (Tabel 4) menunjukkan adanya perbedaan yang bermakna pada analisis data, sebelum dan setelah perlakuan (kelompok Khlorhexidin dan ekstrak mengkudu 50\%), kecuali pada kelompok ekstrak mengkudu $75 \%$. Hal ini menunjukkan terjadinya efek menghambat ekstrak mengkudu terhadap Streptokokus $s p$.

Efek menghambat pertumbuhan bakteri pada ekstrak mengkudu diduga berkaitan dengan senyawa fenol yang dikandungnya. Senyawa fenol merupakan senyawa yang tersebar luas sebagai zat warna alam yang menyebabkan warna pada bunga, kayu dan buah. Senyawa fenol yang terdapat pada buah mengkudu berkisar antara 5,94-36,52g/ 100g material kering. Rohman, dkk. Volk dan Wheeler, Pelczar dan Reid menyatakan bahwa fenol mampu melakukan migrasi dari fase cair ke fase lemak yang terdapat pada membran sel dan menyebabkan turunnya tegangan permukaan membran sel. ${ }^{18}$ Selanjutnya mendenaturasi protein dan mengganggu fungsi membran sel sebagai lapisan yang selektif, sehingga sel menjadi lisis. ${ }^{6}$ Oleh karena itu, fenol berperan sebagai senyawa antibakteri. Senyawa fenol yang terdapat dalam mengkudu diantaranya adalah antraquinon, acubin dan alizarin. Ketiga senyawa ini mengandung zat antibiotik. ${ }^{19,20}$

Kandungan flavonoid pada mengkudu sangat efektif untuk menghambat pertumbuhan bakteri Gram positif. Flavonoid merupakan senyawa antibakteri yang paling banyak terdapat pada buah mengkudu. ${ }^{13}$ Flavonoid bersifat polar sehingga lebih mudah menembus lapisan peptidoglikan yang juga bersifat polar pada bakteri Gram positif dibandingkan dengan lapisan lipid yang nonpolar. Di samping itu, pada dinding sel Gram positif mengandung polisakarida (asam terikoat) yang merupakan polimer yang larut dalam air, yang berfungsi sebagai transfor ion positif untuk keluar masuk. Sifat larut inilah yang menunjukkan bahwa dinding sel Gram positif bersifat lebih polar. Aktivitas penghambatan ekstrak mengkudu pada bakteri Gram positif menyebabkan terganggunya fungsi dinding sel sebagai pemberi bentuk sel dan melindungi sel dari lisis osmotik. Dengan terganggunya dinding sel akan menyebabkan lisis pada sel. ${ }^{11}$

Asam askorbat yang terdapat di dalam buah mengkudu merupakan sumber vitamin $\mathrm{C}$ dan anti oksidan juga berperan dalam mekanisme pertahanan terhadap mikroorganisme. ${ }^{9,21,22}$ Aktivitas ini dimiliki karena kemampuannya membentuk kompleks dengan protein yang larut dan protein ekstraseluler serta dapat membentuk kompleks dengan dinding sel bakteri, sehingga dapat berfungsi sebagai antibakteri. ${ }^{23}$ Pada penelitian ini ekstrak mengkudu berfungsi sebagai antibakteri untuk Streptokokus $s p$ karena menimbulkan efek penghambatan terhadap pertumbuhan bakteri tersebut. Penelitian Dharmawati membuktikan bahwa ekstrak mengkudu mempunyai kemampuan untuk menghambat pertumbuhan bakteri dengan daya hambat kuat terhadap pertumbuhan bakteri Gram positif (Streptokokus mutans). ${ }^{12}$

Menurut Jawetz, pertumbuhan bakteri yang terhambat atau kematian bakteri akibat suatu zat antibakteri dapat disebabkan oleh penghambatan terhadap sintesis dinding sel, fungsi membran sel, sintesa protein atau sintesis asam nukleat. ${ }^{6}$ Pemakaian 
buah mengkudu tanpa memisahkan antara daging dan bijinya akan lebih efektif untuk dimanfaatkan sebagai senyawa antibakteri. Di samping kemungkinan kandungan senyawa aktifnya yang lebih tinggi, penggunaan buah utuh juga akan lebih memudahkan dalam pemrosesannya. ${ }^{24}$ Pada penelitian Dharmawati, mengkudu mempunyai kemampuan untuk menghambat pertumbuhan bakteri dengan daya hambat kuat terhadap pertumbuhan bakteri Gram positif (Streptokokus mutans). ${ }^{12}$ Dapat disimpulkan bahwa ekstrak mengkudu 50\% dan $70 \%$ efektif digunakan untuk alternatif obat kumur, karena dapat menghambat pertumbuhan Streptokokus $s p$ sebagai penyebab plak gigi.

\section{UCAPAN TERIMAKASIH}

Terimakasih kepada Pusat Pendidikan Tenaga Kesehatan Pusat Pelayanan Sumber Daya Manusia Kementerian Kesehatan Republik Indonesia melalui Poltekkes Kemenkes Denpasar yang telah membiayai, mengsuport dan memantau jalannya penelitian ini.

\section{Daftar Pustaka}

1. Departemen Kesehatan RI. Riset Kesehatan Dasar, Badan Penelitian dan Pengembangan Kesehatan Kementrian Kesehatan RI, 2013: 10-11.

2. Departemen Kesehatan RI. Riset Kesehatan Dasar, Badan Penelitian dan Pengembangan Kesehatan, Departemen Kesehatan RI, 2007: 142.

3. Hasan A, Palmer RM. A clinical guide to periodontology, pathology of periodontal disease. British Dent J 2014; 216: 457-61.

4. Hiranya Putri M, Herijulianti E, Nurjanah N. Ilmu pencegahan penyakit jaringan keras dan jaringan pendukung gigi. Jakarta: EGC, 2012: 57-80 : 111- 4.

5. Newman NG, Takei HH, Klokkevold PR, Carranza FA, Eds. Carranza's clinical periodontology. $10^{\text {th }} \mathrm{ed}$. St. Louis: Saunders, 2006: 137- 46.

6. Jawetz, Melnick, Adelberg. Mikrobiologi kedokteran. Alih Bahasa. Hartanto H, Rachman C, Dimanti A, Diani A. Jakarta: EGC, 2008: 199-200: 33.

7. Astoeti TE. Lakukan perawatan gigi menyeluruh. http://www.pdgi-online.com (23 Desember 2010).

8. Mali AM, Behal R, Gilda SS. Comparative evaluation of $0,1 \%$ turmeric mouthwash with $0,2 \%$ chlorhexidine gluconate in prevention of plaque and gingivitis: A clinical and microbiological study. J Indian Society of Periodontology 2012; 16 (3): 386-91.

9. Widayat W. Khasiat buah mengkudu. www. Ekafood.com (30 Agustus 2015).

10. Raiyanti IGA, Untung SB, Dwiastuti SA. Efektifitas kumur-kumur air rebusan daun sirih dan sari buah mengkudu dalam menurunkan jumlah plak skor gigi pada mahasiswa JKG Poltekkes Denpasar. Denpasar : JKG Poltekkes, 2004: 45- 8.

11. Dewi FK. Aktivitas antibakteri ekstrak etanol buah mengkudu (Morinda Citrifolia, Linnaeus) terhadap bakteri pembusuk daging segar. Surakarta: Jurusan Biologi MIPA, Univ. Sebelas Maret, 2010: 25-7.

12. Dharmawati IGAA. Efek ekstrak mengkudu menghambat pertumbuhan Streptokokus mutans penyebab dental plak secara in vitro. Thesis. Denpasar: Program Pasca Sarjana, IKD UNUD, 2011: 51-4

13. Rohman A, Riyanto S, Utari D. Aktifitas antioksidan, kandungan fenolik total dan kandungan flavonoid total ekstrak etil asetat buah mengkudu serta fraksi-fraksinya. J Farmasi Indonesia 2006; 17(3): 136-42

14. Jayaraman SK, Muthu SM. Antibacterial, antifungal and tumor cell suppression potensial of morinda citrifolia fruits extracts. International $\mathrm{Jl}$ of Integrative Biology 2008; 3(1): 44-9.

15. Elifah, Esty. Uji antibakteri fraksi aktif ektrak metanol daun senggani (Melastoma candidum, D Don) terhadap Escherichia coli dan Bacillus subtilis serta profil kromatografi lapis tipisnya. Surakarta : UNS FMIPA, 2010: 10-11.

16. Kusmayati, Agustini NWR. Uji aktivitas senyawa antibakteri dari Mikroalga (Porphyridium cruentum). J Biod. 2007; 8(1): 48-53.

17. Antanasan KB, Janebodin K, Suppakpatana P, Arayapisit T, Chunhabundit P, Rodsutthi JA, dkk. Morinda citrifolia leaf enhances In Vitro osteogenic differentiation and matrix mineralization by human periodontal ligament cells. J Dentistry 2012; 2 (3): 1-7.

18. Efri, Aeny TN. Keefektifan ekstrak mengkudu pada berbagai konsentrasi terhadap penghambatan pertumbuhan bakteri Ralstonia sp. secara in vitro. $\mathbf{J}$ Hama dan Penyakit Tumbuhan Tropika 2004; 4 (2): 83-8.

19. Djauhariya E, Rahardjo M, Ma'mun. Karakterisasi morfologi dan mutu buah mengkudu. Bul Plasma Nutf. 2006; 12 (1): 1-8.

20. Kumarasany B, Manipul S, Duraisunya P, Ahmed A, Mohanaganesh SP, Jeevika C. Role aquos extract of Morinda citrifolia (Indian Noni) ripe fruits in inhibiting dental caries causing Streptokokus mutans and Strptococcus mittis. J Dentistry Tehran University of Medical Sciences 2014; 1(6): 703-10.

21. Pratiwi R. Perbedaan daya hambat terhadap Streptokokus mutans dari beberapa pasta gigi yang mengandung herbal. Dent J 2005; 38 (2) : 64-7.

22. Kresnawaty, Irma, Ahmad Z. Aktivitas antioksidan dan anti bakteri dari derivat metil ekstrak etanol daun (Uncaria gambir). J Littri 2009; 15(4): 145-51.

23. Anonim. Antiseptik sebagai obat kumur peranannya terhadap pembentukan plak gigi.http://www.kalbe. co.id (7 November 2010).

24. Kusmayati Agustin NWR. Uji aktivitas senyawa antibakteri dari Mikroalga (Porphyridium cruentum). Biodiversitas 2007; 8(1): 48-53. 